\title{
Luchino Visconti, mediador entre moda, memória e cinema
}

\author{
Luchino Visconti, a mediator between \\ fashion, memory and cinema
}

[resumo] 0 presente artigo trata da análise e da relação entre o cinema de Luchino Visconti - especificamente em três obras: Morte em Veneza (1971), Os deuses malditos (1969) e Ludwig, a paixão de um rei (1973) - e promove a releitura do figurino enquanto elemento narrativo e constitutivo da filmografia do cineasta, a interface com a moda e a memória e a análise das coleções criadas pelas grifes Chanel (2009/2010) e Miu Miu (2016) a partir dos filmes.

\section{palavras-chave}

cinema; Visconti; moda; costume; memória.

[abstract] The present article deals with the relation between the cinema of Luchino Visconti, especially in three works, Morte a Venezia (1971), The Damned (1969) and Ludwig (1973) and the costume as one of the constitutive elements of his narrative and his cinematography, as well as an interface between fashion and memory and analysis of the collections created by designer labels Chanel e Miu Miu as of movies.

[keywords] movie; Visconti; fashion; costume; memory. 
Moda e cinema são duas formas de linguagem, representação, imagem e expressão que dialogam, apropriam-se reciprocamente, alimentam-se e apresentam, na maioria das vezes, resultados surpreendentes. 0 cinema, desde seu surgimento, tem sido uma das grandes referências da moda e tem ao seu lado um forte coadjuvante, o figurino, que, ao longo do desenvolvimento da sétima arte, tornou-se uma fonte inesgotável de pesquisa de tendências e de desenvolvimento de temas para coleções.

0 objetivo, neste artigo, é discutir a inter-relação entre as obras Morte em Veneza (1971), Os deuses malditos (1969) e Ludwig, a paixão de um rei (1973), dirigidas pelo cineasta italiano Luchino Visconti (1906-1976), isto é, o figurino enquanto narrativa fílmica, a roupa como representação e a memória a partir das releituras e das ressignificações feitas pelas grifes Chanel e Miu Miu em duas coleções, respectivamente em 2010 e 2016, por meio dos três filmes que compõem a trilogia alemã do cineasta Luchino Visconti. Neste ano, em que se celebram 110 anos do nascimento de Visconti e 40 anos de sua morte, uma comemoração mais do que justa para aquele que foi um dos maiores cineastas de todos os tempos.

Muitas são as definições sobre moda. Trata-se de um sistema que se apoia, basicamente, em dois aspectos que pertencem à sua lógica: a efemeridade e a fantasia estética. É mercadoria que encanta, seduz e alimenta o imaginário social de um grupo. Está entrelaçada à sociedade e aos seus movimentos e à cultura de consumo e está presente em nosso cotidiano em áreas diversas, como shoppings, centros culturais, museus e universidades. É cultivada e celebrada pelos indivíduos, pelos grupos, pela mídia - em reportagens, crônicas, produções. Interage com áreas diversas, tais como a História, a Antropologia, a Psicanálise, a Literatura, o Cinema, entre outras, integrando o cenário contemporâneo, representando aspectos e fragmentos de uma dada realidade ou criando outras. 0 filósofo francês Gilles Lipovetsky, autor de O império do efêmero (1989), aborda, nessa obra, a moda como integrante de um campo do pensamento e da reflexão, expressão da modernidade ligada a questões como autonomia, psicologismo e individualismo, impulsionadas pelo consumo e pela cultura de massa. A obra destaca-se por apresentar um pensamento crítico e inovador acerca da ruptura das tradições clássicas presentes na moda e a defesa do individualismo democrático. Um de seus pontos cruciais é discutir o acesso ao bem-estar, ao luxo e ao consumo nas camadas sociais que não se situam no topo da pirâmide. Segundo Lipovetsky (1989, pp. 12-19),

[...] A moda está nos comandos de nossas sociedades; a sedução e o efêmero tornaram-se, em menos de meio século, os princípios organizadores da vida coletiva moderna [...]. A moda consumada vive de paradoxos: sua inconsciência favorece a consciência; suas loucuras, o espirito de tolerância; seu mimetismo, o individualismo; sua frivolidade, o respeito pelos direitos do homem [...]. Na nova era democrática, o progresso coletivo na liberdade do espírito não se fará fora do jogo da sedução; ele se apoiará na forma moda, mas secundado por outras instâncias, reforçado por outros critérios, pelo trabalho específico da escola, pela ética, pela transparência e a exigência própria à informação, pelas obras teóricas e científicas.

Pode-se considerar a moda também como um texto (OLIVEIRA, 2007) que apresenta, assim como nas artes, de maneira geral, estruturas de enredos, narrativas e gêneros que podem ser transmitidas e compartilhadas.

Moda e indumentária são fenômenos culturais e de comunicação. E algumas das maneiras pelas quais um grupo constrói e comunica sua identidade. São comunicativas na medida em que constroem modos não verbais pelos quais se produzem e se trocam significados e valores. (BARNARD, 2003, p. 76) 
Em sua obra Passagens, Walter Benjamin se debruçou na análise de temas como a arquitetura, o cinema, a moda, os magazines, entre demais símbolos da modernidade. Para ele, a moda exprime a dialética entre o novo, o arcaico e 0 sempre igual e, assim como ocorre na modernidade, implica em um mundo de contradições e ambiguidades. 0 novo, para ele, está ligado à morte.

\footnotetext{
[...] A moda inaugurou o entreposto dialético entre a mulher $\mathrm{e}$ a mercadoria - entre o desejo e o cadáver. Seu espigado e atrevido caixeiro, morte, mede o século em braças e, por economia, ele mesmo faz o papel de manequim e gerencia pessoalmente a liquidação, que, em francês, se chama révolution. Pois a moda nunca foi outra coisa senão a paródia do cadáver colorido, provocação da morte pela mulher, amargo diálogo sussurrado com a putrefação entre gargalhadas estridentes e falsas. Isso é a moda. Por isso ela muda tão rapidamente; faz cócegas na morte e já é outra, uma nova, quando a morte a procura com os olhos para bater nela durante um século, a moda ficou devendo à morte. (BENJAMIN, 2006, p. 102)
}

A moda pode ser compreendida como um dos componentes das condições sociais de subjetivação e construção de identidades, estabelecendo uma ampla rede de relações com os indivíduos. A roupa e o corpo criando subjetividades, exprimindo imagens, formas e símbolos.

Com relação ao cinema, este foi percebido enquanto um universo ficcional gerador de uma gama de representações culturais, sociais, visuais e sonoras que captura múltiplas formas de sociabilidades e vivências subjetivas. É uma linguagem imagética constitutiva do tecido social, portador do universo, repertório e imaginário do cineasta e de suas representações acerca dos eventos abordados, que, por sua vez, envolvem conflitos e tensões de uma determinada realidade. Visto como evento, um filme não pode ser considerado um efeito estruturado, mas sim um agente estruturante, portador de materialidade, significados e repertório cultural. Ele pode questionar, discutir ou propor ideias, valores, comportamentos, concepções, assim como paradigmas que envolvem a temporalidade e o poder. Da mesma forma, uma coleção de moda discute narrativas, subjetividades, costumes, relações de gênero, comportamentos, relações socioculturais e padrões estéticos. Moda que se torna igualmente memória afetiva e cultural.

$\mathrm{Na}$ inter-relação da moda com o cinema, o figurino pode ser definido como o conjunto de indumentária e acessórios usado como registro de uma época, forma de narrativa e expressão artística, portador de inúmeros significados. Uma de suas premissas básicas é a de contribuir para a elaboração da personagem, assim como contextualizar, historicamente, o enredo e a narrativa de forma a interagir com 0 espectador, estabelecendo uma relação com a realidade e o mundo cênico.

$\mathrm{Na}$ trajetória histórica da moda, alguns estilistas inauguraram figurinos em variados segmentos artísticos. Influenciado pela companhia Ballets Russes de Diaghilev, que se apresentou em Paris, em 1910, Paul Poiret criou figurinos para espetáculos encenados pela atriz Sarah Bernhardt. A estilista italiana Elsa Schiaparelli (1890-1973) concebeu figurinos para os filmes Every Day's a Holiday (1937), Pigmaleão (1938), No turbilhão parisiense (1938) e Moulin Rouge (1952). Pierre Cardin trabalhou com trajes de época ao confeccionar os figurinos do filme $A$ bela e fera (1946) e Yves Saint Laurent (1936-2008) assinou figurinos para A pantera cor-de-rosa (1964) e A bela da tarde (1967). A estilista Coco Chanel (1883-1971) concebeu os figurinos de A regra do jogo (1939) e 0 ano passado em Marienbad (1967), e, na década de 1950, Hubert de Givenchy (1927-) consagrou a atriz Audrey Hepburn como símbolo de elegância por meio de suas criações para os filmes Sabrina (1954), Cinderela em Paris (1957) e Bonequinha de luxo(1961). 
Muito já se discutiu sobre a filmografia e a vida de Luchino Visconti, até porque elas não se separam - ao contrário, fundem-se. Grande parte de suas obras apresentam um tom operístico, grandiloquente, carregada de alta definição artistica e estética, caracteristicas que se tornaram suas marcas registradas.

A parceria que se firmou entre Luchino Visconti e Piero Tosi, responsável pelos figurinos de vários filmes do cineasta, pode ser considerada como um dos grandes encontros da história do cinema. Tosi, um dos mais completos criadores de todos os tempos, assinou os trajes de cinco filmes do diretor: Belíssima (1954), O leopardo (1963), Morte em Veneza (1970), Os deuses malditos (1969) e Ludwig, a paixão de um rei (1973). Trabalhou ainda com outros dois expoentes do cinema italiano, Pier Paolo Pasolini, criando as vestimentas para o filme Medéia, a prisioneira do amor (1969), e Federico Fellini, em Satyricon (1969).

Nas obras de Visconti, os figurinos adquiriram tamanha força, presença e expressão que não há como separá-los da narrativa filmica. A indumentária simples, quase tosca, de Belíssima, da Itália do pós-guerra, revela o duro cotidiano de pessoas pobres e sofridas, porém, possuidoras de sonhos quase impossíveis, e é retratada de maneira extremamente realista. Senso (1954), uma adaptação literária da novela do escritor italiano Camilo Boito de mesmo nome, narra a história do tumultuado relacionamento entre a condessa Serpieriee o tenente austríaco Franz Mahler, na Veneza de 1866, nos últimos dias do domínio austriaco sobre a região. 0 tom operístico e requintado é dado no início do filme, quando as personagens assistem a encenação de II Trovatore, ópera de Verdi, e, nessa sequência, revela-se todo o esplendor e a beleza das vestimentas. Trata-se de pensar o figurino enquanto memória cultural, constituida por heranças simbólicas presentes em objetos, narrativas, ritos e outros suportes.

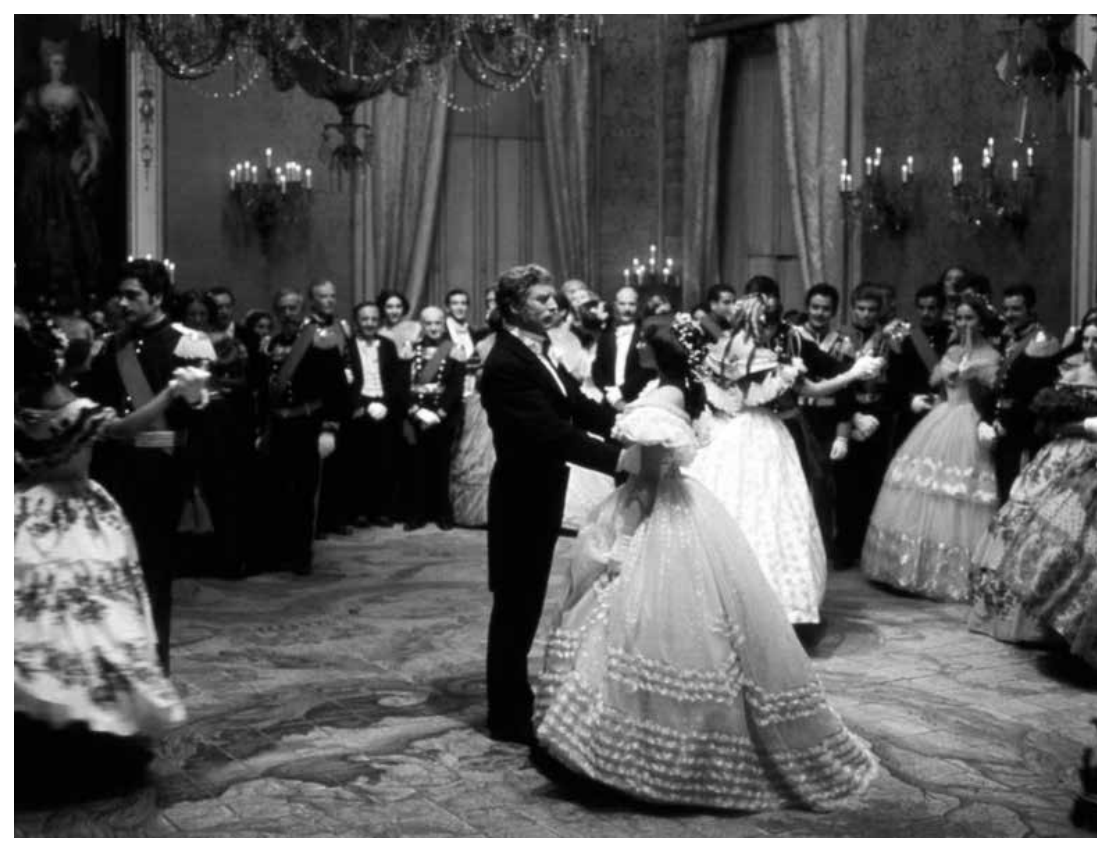

Figura 1 - Inspirado na obra O leopardo, de Tomasi di Lampedusa, o filme é ambientado no periodo que corresponde à unificação italiana, fim do século XIX, e mostra a decadência da nobreza e a ascensão da burguesia. A cena do baile, um dos pontos altos do longametragem, mostra o noivado de Tancredi (Alain Delon) com a plebeia Angelica (Claudia Cardinale), em um arranjo feito pelo tio, o Príncipe de Salinas. Nesta cena, Dom Fabrizi (Burt Lancaster) dança com a noiva. Requinte, beleza e tradição nos figurinos criados por Piero Tosi. Disponivel em: <http://www.blogsoestado.com/emcartaz/files/2013/05/ Leopardo-1.jpg>. Acesso: em 25 set. 2016. 


\section{Requinte, opulência e memória}

O leopardo surpreende, ao longo de suas três horas de duração, pela beleza, pelo luxo e pelos detalhes presentes nas vestimentas, nas joias e nos calçados. Um figurino impregnado pelo requinte e pela memória artística e cultural. Como esquecer o preciosismo da indumentária nos 14 minutos de duração do baile? Para Laurence Schifano, autor da biografia 0 fogo da paixão, "quase tudo que se escreveu sobre o filme faz menção às exigências fanáticas de Visconti: os cem alfaiates, o exército de cozinheiros, os cinquenta dias de filmagem e os quarenta de edição do baile". E acrescenta que, por Visconti ter nascido em 1906, ele pertencia "à época de Mann, Proust e Mahler" (Schifano, 1990, p. 371). Ao investigar a origem e a formação do cineasta, não podemos deixar de notar a semelhança entre seu mundo e o universo aristocrático descrito nas obras dos escritores Marcel Proust e Tomasi diLampedusa, dois autores que tanto influenciaram sua filmografia.

Em sua obra 0 casaco de Marx, o autor Peter Strallybrass apresenta ao leitor as vivências acerca das roupas, da memória, e do casaco do filósofo Karl Marx, um bem material pleno de significações, como aponta: "A mercadoria com a qual Marx começa 0 Capital - o casaco - tem apenas uma tênue relação com o casaco que o próprio Marx vestia em suas idas ao Museu Britânico para pesquisar material para escrever 0 Capital. 0 casaco que Marx vestia entrava e saía da casa de penhores" (STRALLYBRASS, 2008, p. 41). 0 autor mostra a importância dos artefatos culturais sob a ótica da memória: "Quando penso sobre roupas, repenso meu próprio trabalho sobre o início da Inglaterra moderna. Pensar sobre a roupa, sobre roupas, significa pensar sobre memória, mas também sobre poder e posse". Como esquecer a roupa de marinheiro, com suas listras navy, do jovem Tadzio (Björn Andresen), por quem o compositor Gustav vonAschenbach (Dirk Bogarde) nutre uma paixão platônica no filme Morte em Veneza? Nesse sentido, é preciso pensar nos trajes dos filmes de Visconti como criadores de significados diversos, dotados de simbolismos e de representações (STRALLYBRASS, 2008, p. 12).

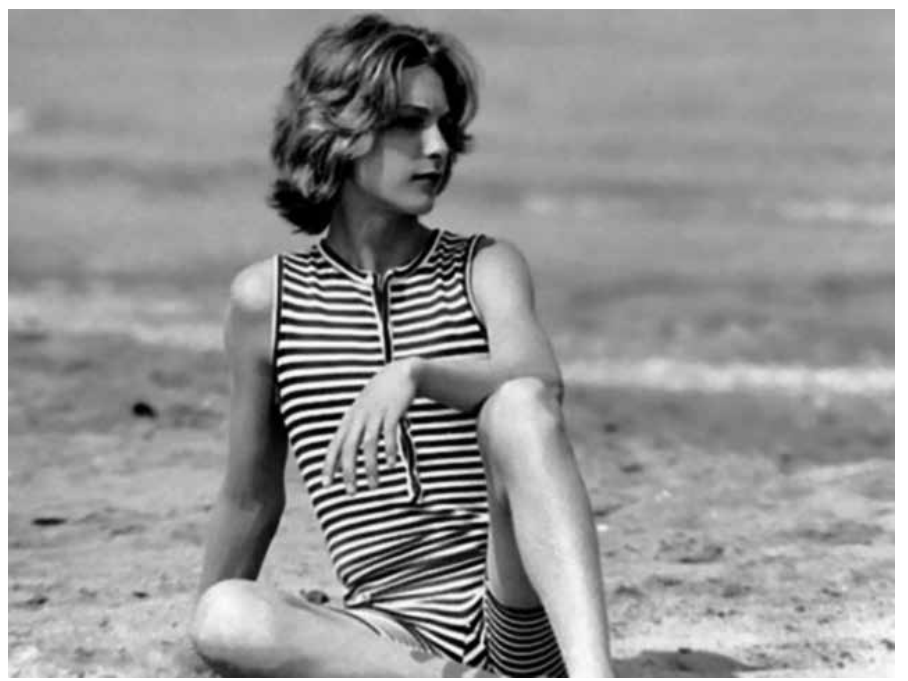

Figura 2 - Morte em Veneza: o marinheiro de Tadzio é sempre revisitado em coleções de moda. Nesta imagem, o jovem efebo em uma cena no Lido, em Veneza.

Disponivel em: <https://s-media-cache-ak0.pinimg.com /5 64x/ 88/4f/84/884f 846e1e0969 0554cb90152663a396.jpg >. Acesso em: 25 set. 2016. 


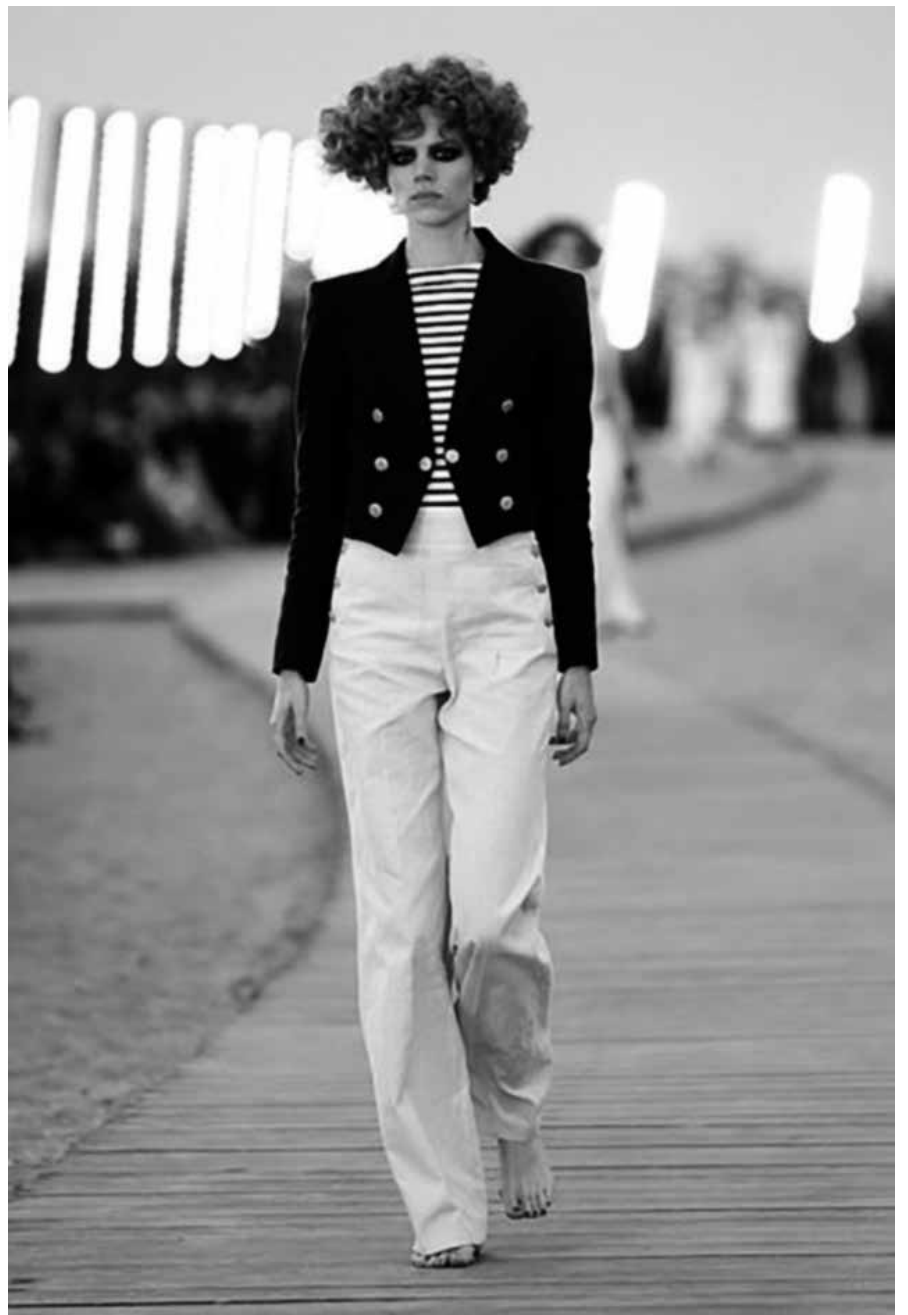

Figura 3 - A roupa de marinheiro na versão contemporânea da coleção cruise da Chanel. 0 desfile, de 2010, ocorreu no Lido, em Veneza, mesmo local onde foi rodado o filme. Disponivel em: <https://fashionview.files.wordpress.com/2009/05/21052009165107191022 7008.jpg?w=304cth=448>. Acesso em: 25 set. 2016.

Podemos ainda pensar o figurino enquanto registro e documento, tendo como referência o documentário Notebook on Cities \& Clothes (1989), que no Brasil recebeu o título $A$ identidade de nós mesmos. Dirigido pelo cineasta alemão Wim Wenders, o filme traz revelações sobre o estilista japonês Yohji Yamamoto a partir de seu método de trabalho: pesquisa sobre fotografias e a memória presentes nas vestimentas antigas, imagens de pessoas de várias etnias e de suas roupas, a busca pela simplicidade, a efemeridade da moda. Essa acuidade que o designer empreende em seu trabalho pode ser constatada no cinema de Visconti.

Luchino Visconti iniciou-se no cinema em 1936, como assistente do cineasta francês Jean Renoir (1894-1979), no filme Une Partie de Campagne. Seu primeiro grande filme, rodado na Itália, é Obsessione, de 1943, e em 1948, contratado pelo Partido Comunista Italiano, fez o documentário La Terra Trema, considerado o precursor do neorrealismo. Em 1951, dirigiu Belissima, e, em 1954, Senso, que 
recebeu no Brasil o título Sedução da carne. A relação com a literatura, a ópera, a pintura, o teatro e o cinema está presente na sua filmografia. Mas é, sobretudo, a partir da década de 1960 que o cineasta passa a realizar verdadeiras obras primas. Se os primeiros filmes do diretor são realistas - La Terra Trema e Belíssima -, é a partir de 0 leopardo que suas obras adquirem requinte, opulência, sofisticação, ao mesmo tempo que dialogam com o tempo e a memória.

Em 1962, fez um de seus grandes sucessos de público e crítica, Rocco e seus irmãos, e, no ano seguinte, em 1963, outro elogiado filme, O leopardo, baseado no livro homônimo do escritor italiano Tomasi diLampedusa, ganhador da Palma de Ouro no Festival de Cannes. Outros grandes filmes realizados por Visconti são Vagas estrelas da Ursa Maior(1965), O estrangeiro (1967), Os deuses malditos(1969), Bocaccio 70 (1962), Morte em Veneza (1971), Violência e paixão (1974), Ludwig, a paixão de um rei (1973) e 0 inocente (1976), este baseado na obra literária de Gabriele D'Annunzio. Boa parte dos argumentos de seus filmes foi resultante de adaptações de textos literários de autores renomados, como Giuseppe Tomasi diLampedusa, Dostoievski, Thomas Mann e Albert Camus. Entre seus colaboradores, destacam-se CesareZavattini, Alberto Moravia e Giorgio Bassani. No teatro, dirigiu peças de Tchekhov, Arthur Miller, William Shakespeare, Tennessee Williams e Jean Cocteau. Tornou-se igualmente famoso como diretor de óperas, realizando e dirigindo espetáculos inesqueciveis de autores como Verdi, Bellini, Strauss e Puccini, tendo como parceira a cantora lírica Maria Callas. Sua maestria como diretor não abria espaço para dúvidas, assim como o seu tratamento meticuloso da música, do figurino, do cenário e da fotografia.

0 cinema influencia a moda ou a moda influencia o cinema? Ambos inte-

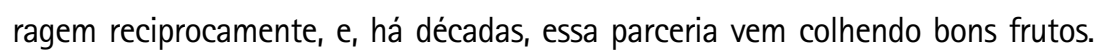
Trata-se de discutir não somente as coleções que se inspiraram nos filmes de Visconti, mas também de perceber a relação entre as duas linguagens e a apropriação entre ambos.

No caso da moda contemporânea, a apropriação e a hibridação têm apresentado releituras sem compromisso com a fidedignidade, sem regras ou normas anteriormente ditadas pela alta-costura ou pelo prêt-à-porter. Na contemporaneidade, segundo Lipovetsky (1989, p. 45),

A moda irrompe em coleções singulares e incomparáveis, cada criador prossegue sua trajetória própria, avançando seus próprios critérios. A moda aproximou-se ao mesmo tempo da lógica da arte moderna, de sua experimentação multidirecional, de sua ausência de regras estéticas comuns. Criação livre em todas as direções, na arte como na moda: da mesma maneira que os encenadores contemporâneos apropriam-se livremente do repertório oficial e transgridem, abolindo a autoridade do texto e os princípios exteriores à criação do 'palco'; assim também os criadores liquidaram a referência implícita a um gosto universal e reinvestem ironicamente, anarquicamente, nos estilos do passado. 0 teatro de texto cedeu lugar a um teatro de imagens, intensidades e de choques poéticos; a moda, por seu lado, relegou os desfiles discretos dos salões da Alta Costura em favor do 'efeito pódio', dos shows de som e luz, do espetáculo da surpresa.

\section{Reminiscências, a captura do tempo em Morte em Veneza}

Escrita por Thomas Mann em 1911, a novela Morte em Veneza (1971) tem como protagonista Gustav von Aschenbach, um respeitado escritor que vive uma crise existencial e começa a questionar sua carreira e sua obra. 0 compositor escolhe Veneza paras suas férias e, ao hospedar-se em um luxuoso hotel à beira-mar, encontra 
o jovem Tadzio, por quem se apaixona e se torna obcecado por sua beleza singular. Tadzio representa o modelo de perfeição, harmonia e rigor procurado por Aschenbach em suas composições. A novela de Thomas Mann discute ainda outras questões, como a passagem do tempo, a decadência física do escritor e a Europa em meio ao confronto bélico. Na adaptação para o cinema, Morte a Venezia (1971), produção ítalo-francesa, Visconti transformou Aschenbach em músico, reafirmando sua admiração por Mahler, utilizando, inclusive, trechos da $3^{\text {a e }} 5^{\text {a }}$ sinfonias do compositor.

Para Visconti:

0 tema desta narrativa, ainda que transformado em morte da arte ou preponderância da política sobre a estética, continua presente. Sempre me atraiu a possivel divergência entre as aspirações estéticas e a vida de um artista, entre a sua existência, que aparentemente ultrapassa a história, e a sua participação nas condições históricas burguesas'.

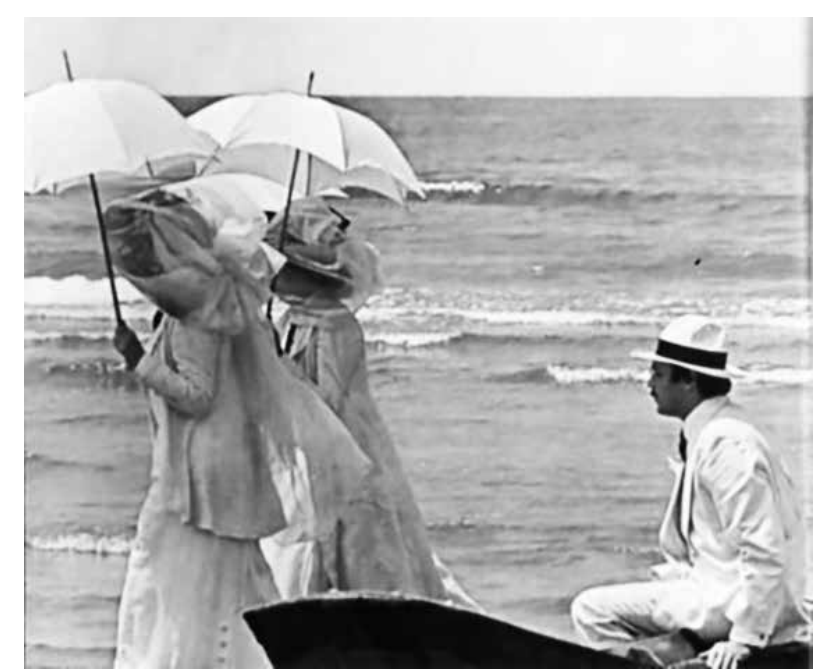

Figura 4 - Morte em Veneza. 0 compositor Aschenbach (Dirk Bogarde) em Veneza. A cena do filme evoca uma obra impressionista. Disponivel em: $<$ https://armonte.files.wordpress. com/2011/02/morte_em_veneza1.jpg >. Acesso em 25 set. 2016.

Belos cenários evocam a pintura impressionista por meio de enquadramentos primorosos e perfeitos, registrando todo o esplendor de uma época. 0 requinte do mobiliário, os vasos de orquídeas, as toilettes femininas e masculinas e, sobretudo, a beleza apolínea e dionisíaca de Tadzio são aspectos da narrativa viscontiana. 0 amor platônico, idealizado pelo maestro Aschenbach, tem, no adolescente, realizados os ideais da perfeição e do rigor estéticos perseguidos por ele e tão almejados em suas composições. A epígrafe do filme anuncia o seu desenrolar: "Quem viu a beleza, viu a morte". Muitos closes são usados pelo cineasta para ressaltar o jovem efebo.

No rosto de Tadzio, mais que o desejo de beleza, persiste a busca de imagens significantes em meio à fragilidade do tempo. Para além da dor da perda, do horror de saber que tudo que é belo deve morrer, mas ainda assim encontrar a beleza, quando sentir-se em casa é de novo possível, o esquecimento se faz sem culpa, a melancolia se torna leveza. Leveza de redenção da melancolia, pela melancolia. (LOPES, 1999, p. 211) 


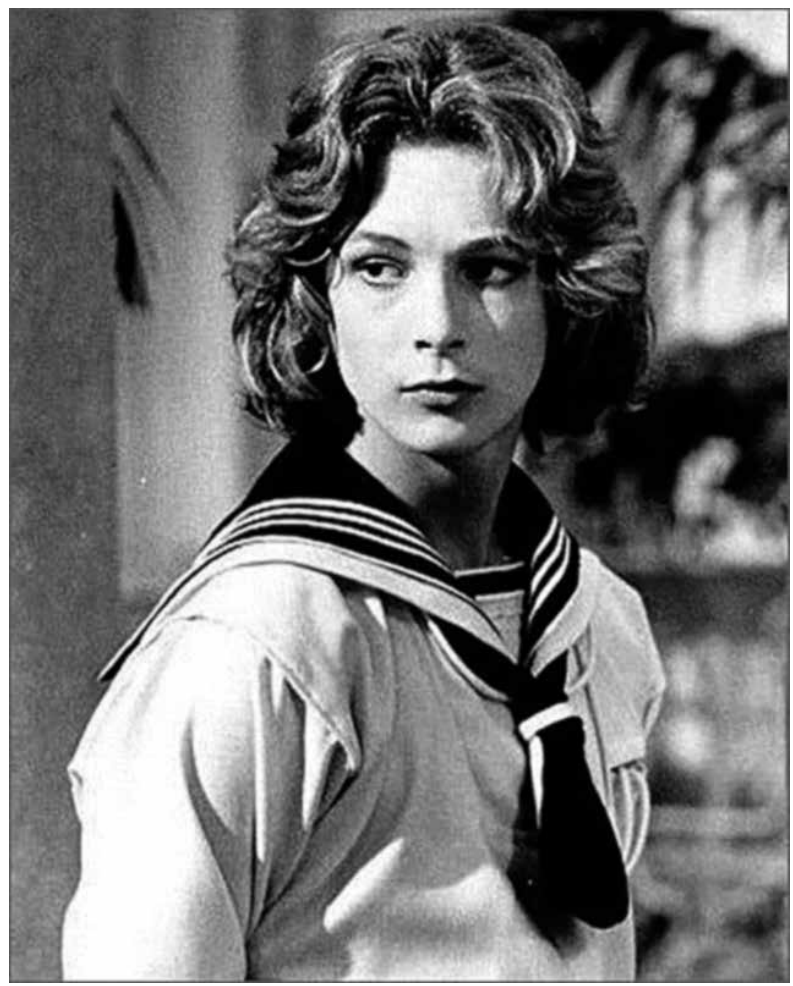

Figura 5 - Morte em Veneza. A beleza emblemática do jovem Tadzio, por quem o compositor Aschenbach nutre uma paixão platônica. 0 filme foi inspirado na novela Morte em Veneza, de Thomas Mann. Disponivel em: <https://s-media-cache-ak0.pinimg. com/564x/88/4f/84/884f846e1e09690554cb90152663a396.jpg >. Acesso em: 25 set. 2016.

0 filme é ambientado em Veneza, em 1911, e assinala o fim da Belle Époque, período marcado na Europa por uma cultura urbana cosmopolita, pela estabilidade política e econômica e intensa inovação no campo das artes que, em geral, iniciou-se no fim do século XIX e durou até 1914, ano em que eclodiu a Primeira Guerra Mundial. Uma percepção proustiana acerca do tempo, da memória, das reminiscências, da finitude, do tarde demais, é capturada pelo cineasta.

0 filósofo Gilles Deleuze afirmara, certa vez, que Visconti era o cineasta do tempo, e, em uma conferência proferida em 1987, questionara o que é ter uma ideia em cinema. A esse respeito:

0 que faz com que um cineasta tenha vontade de adaptar, por exemplo, um romance? Parece-me evidente que é porque ele tem ideias em cinema que fazem eco àquilo que o romance apresenta como ideias em romance. E com isso se dão os grandes encontros. (PAULINI, 2010, p. 1)

Ao retratar a beleza, a harmonia, a decadência e a finitude em Morte em Veneza, o mundo dos aristocratas (O leopardo e Ludwig), da decomposição social e familiar (Os deuses malditos, Violência e paixão), o diretor falava, ele próprio, de sua existência. Luchino Visconti nasceu em berço nobre, em novembro de 1906, em Milão, filho de pai aristocrata e de mãe da alta burguesia. Na década de 1960, filiou-se ao Partido Comunista e, assim, a aparente contradição entre o aristocrata e o comunista contribuiu muito para que se tornasse o mais refinado cineasta a revelar mundos conflitivos, antagônicos e decadentes. 
Inspirada no filme Morte em Veneza, a coleção cruise, de 2009/2010, da grife Chanel, foi apresentada em Veneza, em maio de 2009, em um fim de tarde, tendo o Lido como cenário, o mesmo da locação do filme. 0 marinheiro de Tadzio, na versão contemporânea, ganhou várias interpretações e manifestou-se em diversas peças, como jaquetas, blusas, bermudas, calças, cardigãs e tailleurs, apresentando uma moda atemporal, elegante e minimalista. Vestidos sofisticados, como os utilizados pela atriz Silvana Mangano, que interpreta a mãe de Tadzio no filme, em silhuetas longa e curta, rendas, transparências, babados e brilhos, botinhas curtas, criados a partir de um figurino impecável. Não faltaram o chapéu e a sombrinha de época, usados por Mangano, detalhes que enriquecem a narrativa do desfile de moda da Chanel.

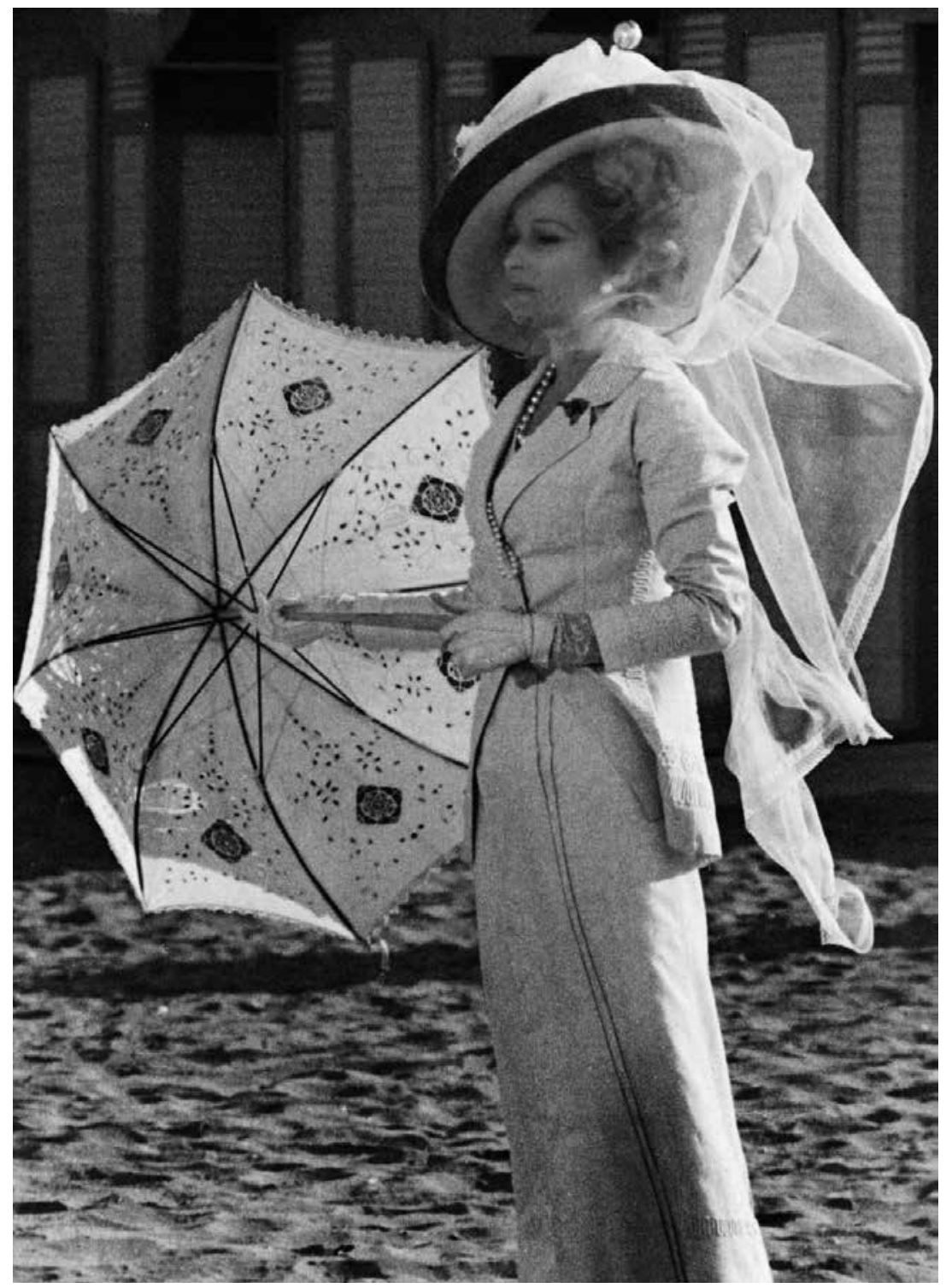

Figura 6 - A bela atriz italiana Silvana Mangano, como a aristocrática matriarca. 0 figurino de Morte em Veneza é assinado por Piero Tosi. Disponível em: <https://s-media-cache-ak0. pinimg.com/736x/8d/16/5a/8d165a87315be9bb353ab2f8471707c1.jpg>. Acesso em: 25 set. 2016. 


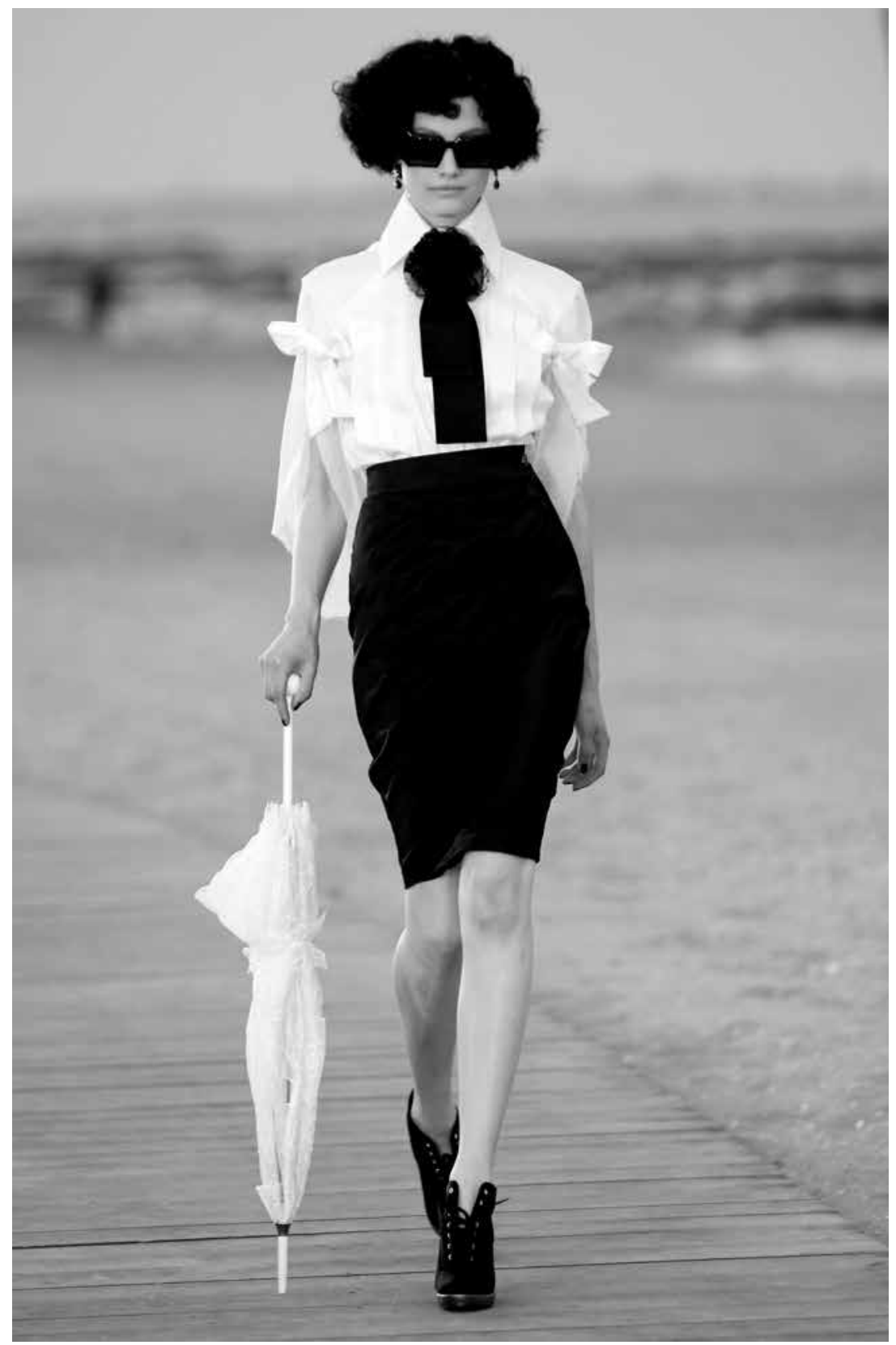

Figura 7 - A sombrinha estilizada, usada no filme Morte em Veneza, pela atriz Silvana Mangano, compõe o look contemporâneo do desfile da Chanel. Disponível em: <http://2. bp.blogspot.com/_xFZOB07-050/Sg3MmM4SkHI/AAAAAAAABjk/qg9NelxQfrc/s400/ CHANEL.jpg >. Acesso em: 25 set. 2016.

\section{Sobre o período abordado no filme, o crítico Anatol Rosenfeld (1994, p. 180) analisa}

A insistente focalização da moda pré-primeira guerra mundial, daquela manifestação cultural, portanto, cuja essência é o caráter efêmero - aliás apreendido em traços salientes e quase caricatos - reforça a impressão de vaidade ou vanitas e acrescenta, para nós, pósteros, de leve, a de uma mascarada que encobre, sob a superfície festiva e vistosa, a frágil transitoriedade, a íntima exaustão e a decadência. 


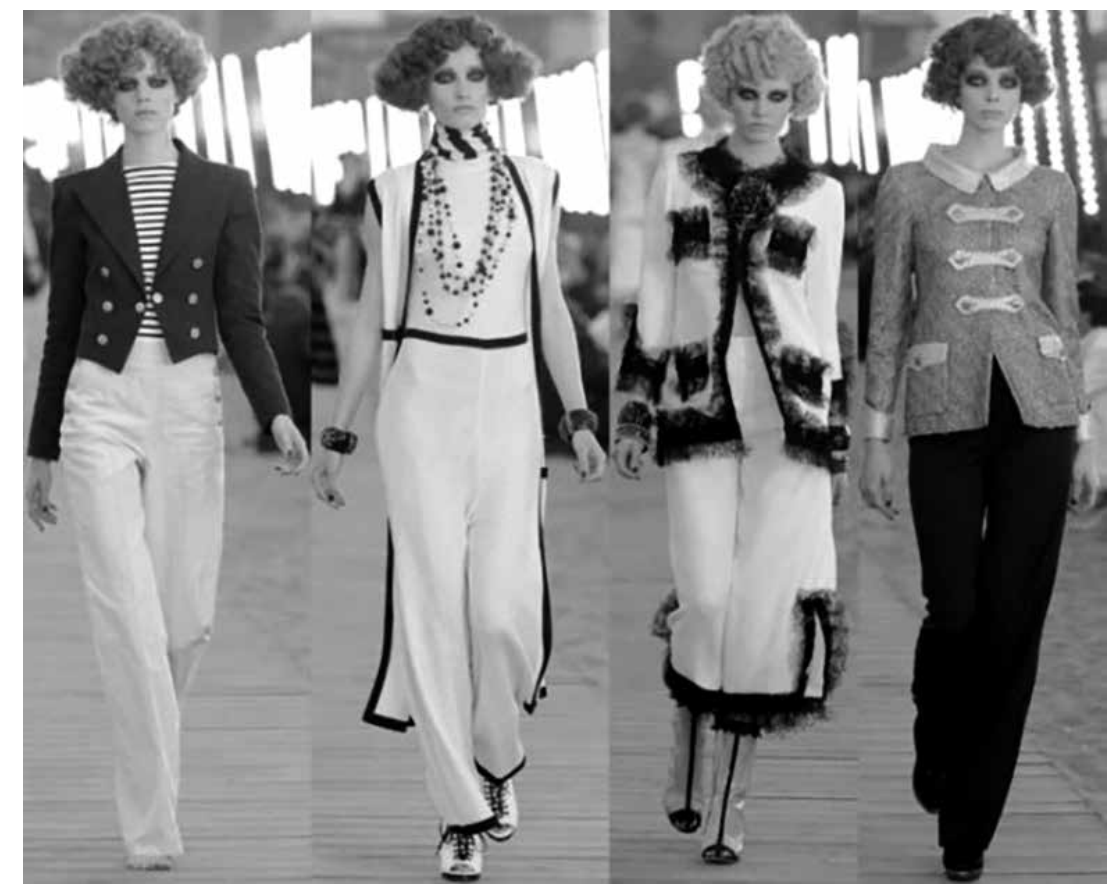

Figura 8 - Looks de Chanel inspirados no filme Morte em Veneza. Todas as modelos usaram cabelos curtos e maquiagem forte nos olhos, alusão à ambiguidade e à androgenia do personagem Tadzio. Disponivel em: <http://www.abril.com.br/imagem/chanel-cruisecollection-2010-05g.jpg>. Acesso em: 25 set. 2016.

Todas as modelos exibiam cabelos curtos, estilo Chanel, muitos closes nos rostos, que no filme, são utilizados como forma de evocar fotografias, portraits e, sobretudo, como forma de reter o presente, o momento e o tempo. A maquiagem pesada nos olhos, aludindo à androginia e à ambiguidade do personagem Tadzio, assim descrito por Laurence Schifano:

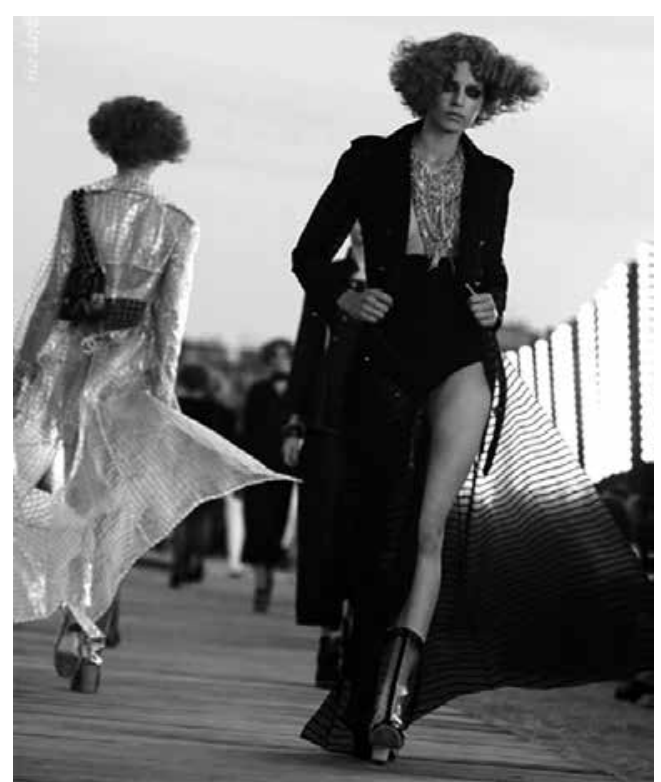

Figura 9 - Versão pós-moderna do figurino do filme Morte em Veneza, coleção cruise Chanel 2010. Disponivel em: <http://www.estilovanguarda.com.br/wp-content/ uploads/2009/05/c5.jpg>. Acesso em 25 set. 2016. 


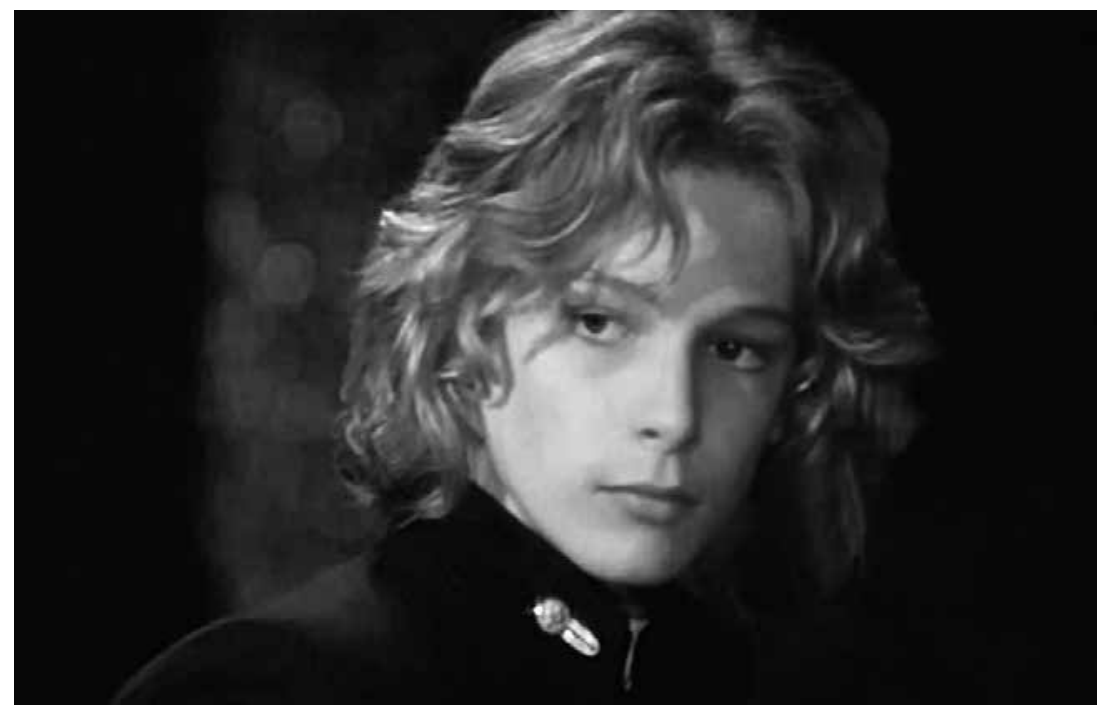

Figura 10 - A beleza atemporal do personagem Tadzio. Disponível em: <http://api.ning. com/files/OHO*5vFbdAxIAnlyBNphbPpFd6AvnpLioYzjPdEdiOs0pdlixOn9doom7BLqI5KVjYB 5oomMzsBgB8Vo5kxSGhSi-vf8ZoOd/bjornandresen1>. Acesso em 25 set. 2016.

Anjo da manhã e da morte, iria conservar ao longo de todo o filme aquele sorriso enigmático, carinhoso e mudo, que é o de certos anjos de Leonardo da Vinci. A dificuldade era retratar tudo a bico de pena, com uma delicadeza ambígua [...]. Contemporâneo de Mahler, Proust também estava presente no filme, no olhar elegíaco sobre um mundo desaparecido, no apelo à arte como recriação de uma pátria perdida, que torna a morte 'menos inglória, talvez menos provável', e na aspiração que, segundo Visconti, não é 'nem decadente, nem estética, nem hedonista, mas que procura de maneira mais séria e, no fundo, mais grega, atingir uma perfeição e um equilibrio completo'. (SCHIFANO, 1990, pp. 386-387)

Ao reconstruir o figurino e o cenário do filme, a grife Chanel nos conduz ao imaginário da época obra por meio de representação e narrativa que abarcam a várias dimensões daquela realidade. A cultura do bem-estar, do lazer (coleção cruise), do consumo e do individualismo democrático, temas tão bem tratados por Lipovetsky, aparece como uma moda jovem, contemporânea, assim como a valorização e a diversidade de estilos, formas e materiais têxteis. A referência ao neodandismo, uma das tendências da década de 1980, está presente em algumas criações. A evocação do espetáculo e da criação, a cultura do hedonismo e do individualismo, como estratégias de sedução geradas pela sociedade de consumo, o prazer e a liberdade no vestir são elementos vistos nessa coleção, na qual conceitos presentes na obra do filósofo francês são assimilados.

\section{Um altar para ícones}

The Damned (1969), dirigido pelo cineasta, é uma produção realizada entre Estados Unidos e Itália e recebeu no Brasil o título Os deuses malditos. Um filme violento, ambientado na Alemanha nazista, que narra o envolvimento do clã Essenbeck (que simboliza a família Krupp, proprietária do império do aço na Alemanha) com o regime totalitário. 0 magnata da indústria siderúrgica, o barão Joachim von Essenbeck, anuncia, em um jantar de aniversário, que sua empresa vai pactuar com o nazismo, decisão que provoca conflitos e disputas que levam o clã à desagregação, à decadência e à tragédia final. Assim como em 0 leopardo, Visconti mostra os conflitos entre classes sociais e a histórica inadaptabilidade da aristocracia e da alta burguesia às mudanças do mundo moderno. 


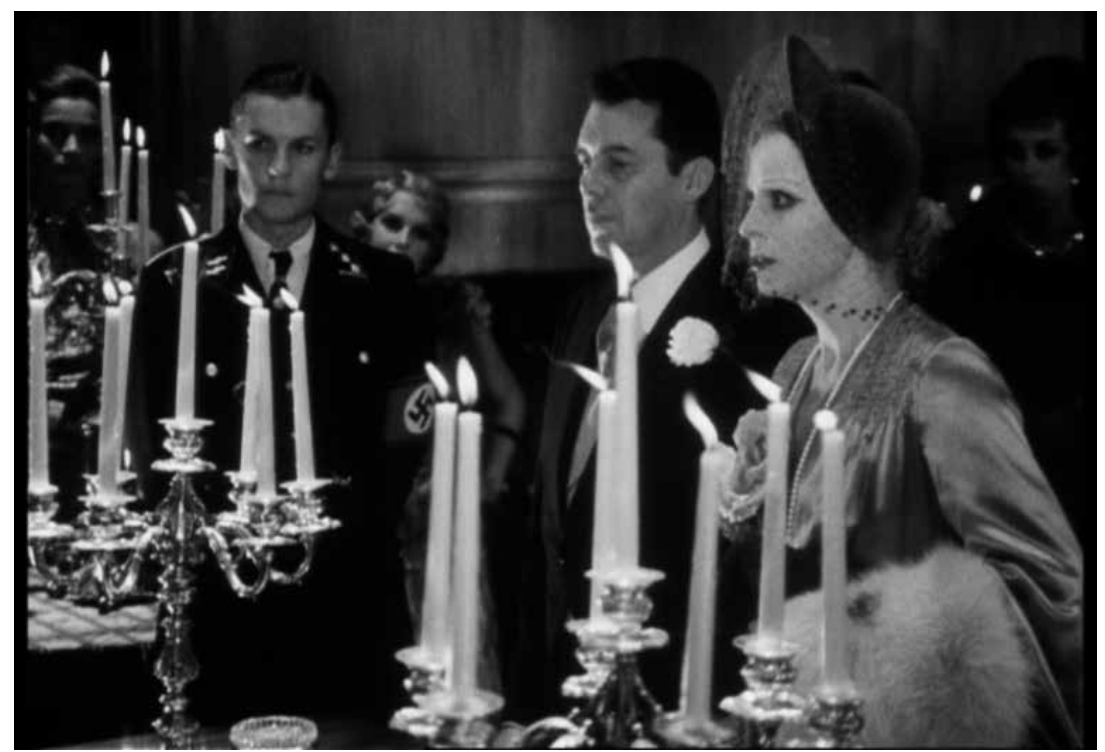

Figura 11 - Os deuses malditos: a trágica história do clã Essenbeck que adere ao nazismo. Decadência, amor, ódio e traição são elementos dessa obra assinada por Luchino Visconti e com figurino de Piero Tosi. Disponivel em: <http://2001video.empresarial.ws/blog/wpcontent/uploads/2012/05/203.jpg >. Acesso em: 25 set. 2016.

0 filme revela as ambivalências que colocam, lado a lado, poder, sedução, disputa, amor, autodestruição e tragicidade. Segundo o critico Luiz Carlos Merten, Visconti "criou os 'Essenbecks' baseando-se nos 'Buddenbrooks' de Thomas Mann, mas também em Shakespeare, elementos trágicos de 'Hamlet' e 'Macbeth"'"2.

Comentário: Os Buddenbrook (1901) é o primeiro romance do autor, laureado com o Nobel de literatura em 1929. Inspirado em sua própria família, Thomas Mann narra a história trágica de uma família burguesa do século XIX, por meio de quatro gerações, em uma cidade com todas as características de Lübeck, terra natal do escritor. Thomas, Christian e Antoine, filhos do patriarca Jean, veem suas vidas destroçadas pelo fracasso financeiro e pelos dramas pessoais. Impactante, dramático e trágico.

[...] Malditos deuses modernos, cujos traços de divindade estão ligados ao poder financeiro, desprezam a ética liberal, forjando para si próprios comportamentos a rasgar quaisquer limites. Como a aristocracia siciliana de 0 leopardo, ou a aristocracia e a burguesia proustianas tinham códigos próprios, suas leis particulares. (PAULINI, 2010, p. 75)

0 filme mereceu a seguinte crítica da filósofa Gilda Mello e Souza:

0 conhecimento do nazismo reveste-se, pois, em Visconti, de uma extraordinária precisão documentária, mas em seguida esta é afastada parcialmente, em proveito de um jogo hábil de sinais e significados. Daí a importância que adquire a correlação entre a roupa civil, o uniforme, a insígnia, a bandeira, a música, a decoração, os gestos, os nomes, os lugares [...] "os deuses malditos" manifestam, portanto, um agudo conhecimento político, tornado singularmente eficaz pela força da estrutura oculta, que a análise desvenda. Mas se não conhecêssemos os fatos e não pudéssemos 
avaliar o rigor com que Luchino Visconti os transfigura, efetuando uma habilissima redução estrutural, o filme guardaria ainda assim o seu impacto de obra de arte, pela coerência do primeiro nível de significação, isto é, a história da disputa pelo poder econômico dentro de uma família ${ }^{3}$.

Ludwig (1973) recebeu o título de Ludwig, a paixão de um reié o último filme da trilogia alemã. As principais fases da vida do rei da Baviera, interpretado pelo ator Helmut Berger, são mostradas desde seu coroamento, em 1864, até sua deposição seguida de morte, em 1886. Assim como em Os deuses malditos, Ludwig mostra a ascensão e o declínio do poder. A música de Richard Wagner, o figurino impecável assinado por Piero Tosi (a obra foi indicada ao Oscar por Melhor Figurino, 1974) retratando o período do romantismo, as telas do pintor alemão David Friedrich, reproduzidas em algumas cenas, fazem desse filme uma obra com grande apuro estético e um retrato, uma discussão sobre o poder, temática que já havia sido abordada em 0 leopardo, Senso e Os deuses malditos. Visconti cria uma narrativa em que o tempo histórico se opõe ao tempo mítico. 0 fim do reino da Baviera, em detrimento da hegemonia prussiana, e a biografia de um rei que, em estado de autodestruição, é traído e destituído.

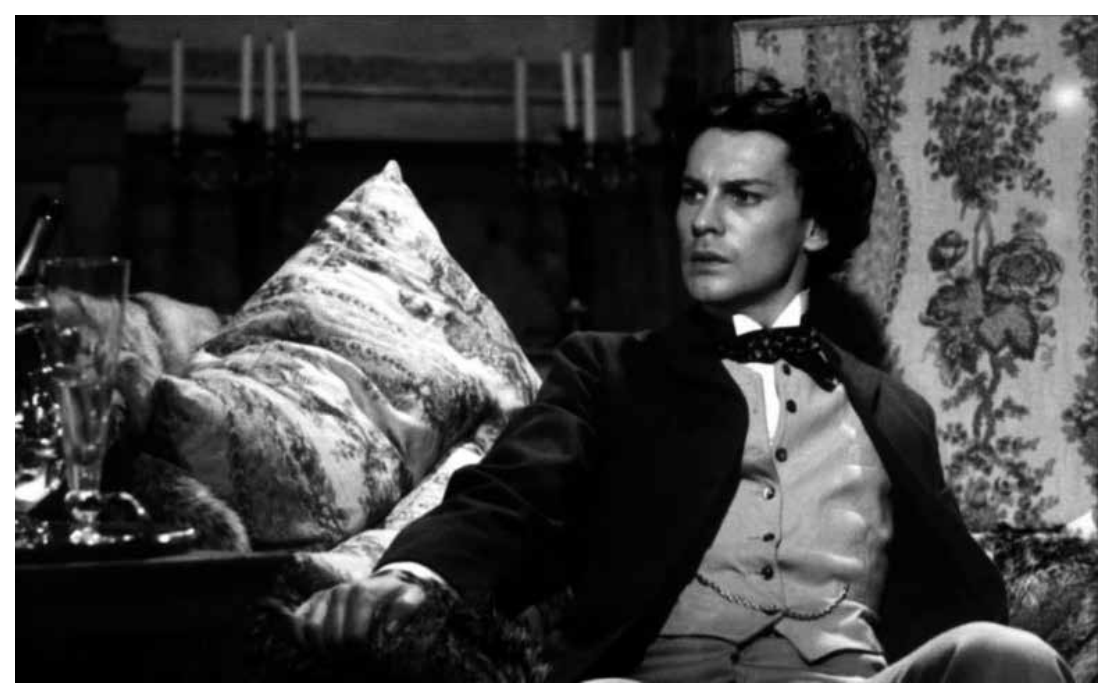

Figura 12 - 0 ator Helmut Berger interpreta Ludwig. Visconti mostra as principais fases da vida do chamado rei louco da Baviera, considerado o mecenas do compositor Richard Wagner. Requinte na encenação, ambientes luxuosos e figurino impecável, assinado por Piero Tosi (indicado ao Oscar), são algumas das características da obra filmada na Alemanha, em 1972. Disponível em: <http://memorialdafama.com/artistas/HelmutBerger3. jpg >. Acesso em: 25 set. 2016.

0 cinema de Visconti é um altar para ícones. Seus personagens são os próprios atores, ícones forjados por uma superação em tensão do prosaico pelo histórico, do príncipe Fabrizio de Salina, ligado a uma ética aristocrática inútil no mundo burguês, a Ludwig, dilacerado a uma ética estética e a ideia católica do pecado, e ao professor, preso a uma ética humanista, de tom esquerdista, do pós-guerra. Em todos, a sensação de serem tardios, fora do seu tempo. Demasiado tarde para viverem no mundo que surge e demasiado cedo para serem entendidos. (LOPES, 1999, p. 208) 
Coube, mais uma vez, a Piero Tosi desenvolver os figurinos para os filmes Os deuses malditos e Ludwig. Em The Damned, o figurino da familia Essenbeck, em especial das personagens femininas, interpretadas pelas atrizes Ingrid Thulin e Charlotte Rampling, é composto por tailleurs, vestidos longos, blusas com rendas, colares e brincos de pérolas, que retratam a elevada condição social. Os trajes masculinos são, essencialmente, marcados por ternos escuros e casacos longos, em cor preta, evocando um tipo de narrativa do período nazista. Para Ludwig, Tosicriou trajes extremamente requintados e luxuosos, com uma elegância militarista típica do império austro-húngaro. Tosi recebeu, em 2013, o prêmio Oscar honorário pelo conjunto de suas criações.

Inspirada nos filmes Ludwig e Os deuses malditos, a grife italiana Miu Miu prestou homenagem ao cineasta ao apresentar, em fevereiro de 2016, na Itália, a coleção pre-fall 2016. Na primeira parte do desfile, vê-se uma coleção inspirada em uma Bavária do século XIX, aristocrática, de ar setentista, imaginária, com destaque para cores inusitadas, como o laranja, 0 verde e o roxo, que deram um feito cool a imagens retrô. Mistura de cores e materiais, como lã, seda, tricô handmade, veludo cotelê, couro, cetim e renda guipire, arrematados por meias bicolores e escarpins em veludo com salto de pele. A sobriedade vista no desfile é marcada por vestidos longos, tailleurs revisitados, colares de pérolas, brincos de cristais, casacos enormes em xadrez e listras, que remetem ao clima austero vigente na Alemanha da década de 1930, apresentada com doses de dramaticidade, leveza e um pouco de humor. Pode-se afirmar que, nesse desfile, a coleção inspirou-se também na década de 1980, época de grande reviravolta na moda.

[...] os anos 1980 anunciaram um novo ideal feminino. A glamazon requintada e arrumada, percorrendo a passarela em seus saltos altos, representava o poder e a sexualidade da mulher de negócios contemporânea. À medida que mais muIheres começaram a entrar na sala da diretoria, o cardigã modesto ou saia longa ondulante da década anterior foram descartados a favor da alfaiataria de ombros acentuados, e a minissaia reapareceu [...]. A jaqueta era usada com uma minissaia combinando. Ao contrário de sua versão anterior dos anos 1960, que fazia referência ao elemento ingênuo do look, a saia longa dos anos 1980 exprimia poder e liberdade. (FOGG, 2008, pp. 436-437)

Na visão benjaminiana, toda moda é uma forma de rememoração, um fenômeno social que se atualiza por meio do passado, ressignificando o presente, revelando a história descontínua. 0 espetáculo dialético da moda deve-se à configuração do novo a partir de eventos ocorridos. A moda, para Benjamin (1994, p.230), tem "um farol para o atual", sendo possivel identifica-la em qualquer lugar do passado. Nessa coleção, a grife desvendou e interpretou o que pertence ao imaginário de duas épocas distintas, interagindo com seus códigos, símbolos, significados e ideologias, reconstruindo-os e atribuindo-lhes novos significados. 


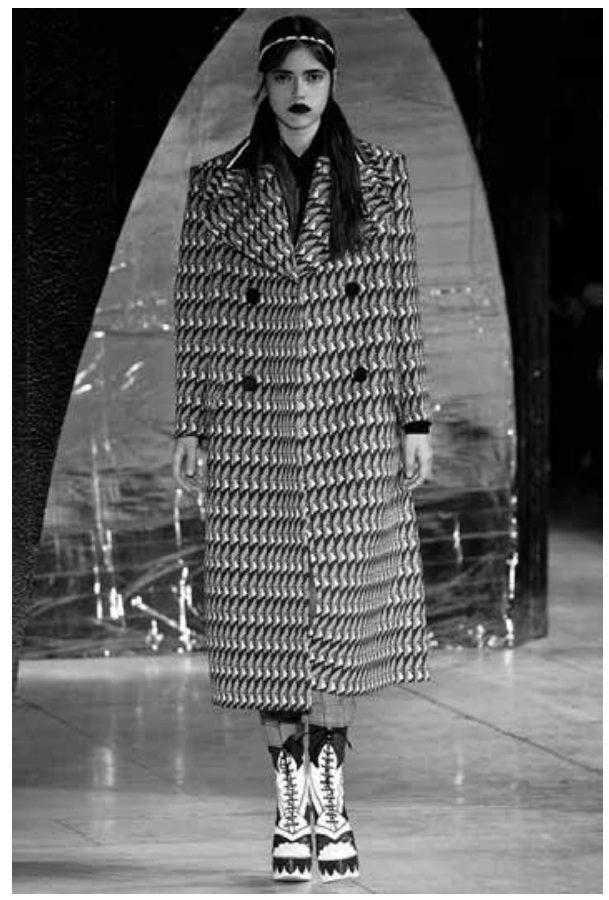

Figura 13 - A alfaiataria da coleção Miu Miu 2016, livremente inspirada nos filmes Os deuses malditose Ludwig. Disponivel em: <http://ffw.com.br/app/uploads/desfiles/2015/03/ Miu Miu-rtw-paris-inverno2016-3.jpg>. Acesso em: 25 set. 2016.

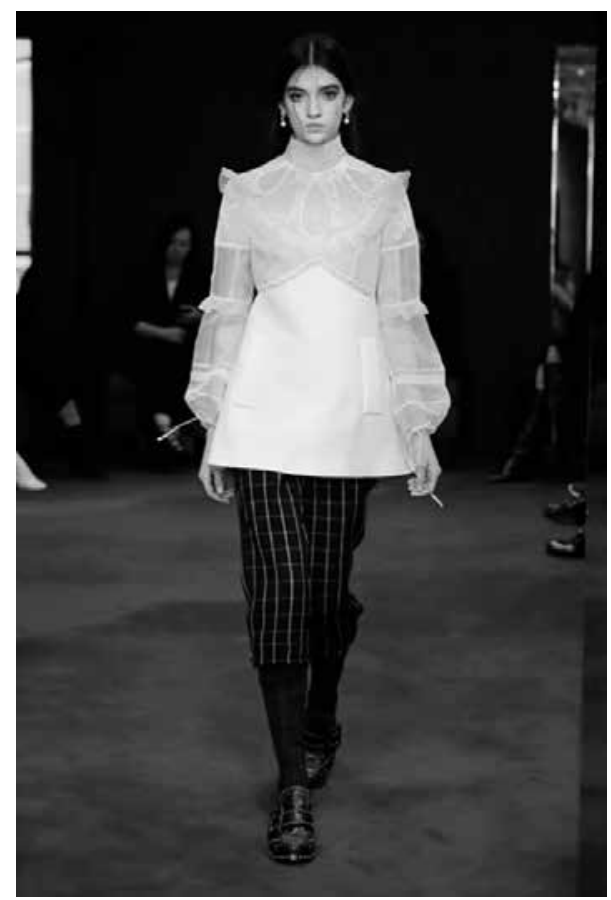

Figura 14 - Transparência e leveza no modelo da Miu Miu, coleção 2016, inspirado no figurino da baronesa Sophie von Essenbeck, personagem do filme The Damned. Disponível em: <http://www.lilianpacce.com.br/desfile/miu-miu-pre-outono-inverno-201617/>. Acesso em: 25 set. 2016.

0 cinema e a moda são produtores de discursos que ajudam a dar visibilidade às representações sociais em torno das identidades culturais, permitem compreender tanto os enfrentamentos quanto as permanências e as transformações nos mais diversos campos. A partir da releitura dos filmes de Visconti, torna-se 
explícito que as duas grifes dialogaram com o imaginário, com o passado e o presente, reinterpretando eventos abordados nas obras filmicas.

\section{Considerações finais}

A moda não só antecipa o futuro como retorna ao passado, revitalizando-o, promovendo uma dialética na qual o novo é criado a partir da relação passado/ presente. Isso nos mostra o quanto essa linguagem não pode apenas ser compreendida como um mosaico de imagens, mas sim como um entrecruzamento de aspectos políticos, culturais, artísticos e sociais.

Em contrapartida, para Gilles Lipovetsky (1989, p.159), a moda é "aquela que reordena a produção e o consumo de massa sob a lei da obsolescência, da sedução e da diversificação". Trata-se de um fenômeno social regido pela diversidade estética, pela fantasia, pela originalidade, que assinala a diferença, positivamente, entre os individuos ao mesmo tempo que promove a autonomização do gosto. Uma lógica social dotada de implicações culturais, sociais e psicológicas, cujo processo está associado ao desenvolvimento das sociedades capitalistas e democráticas. 0 elemento que une essas características é, para o autor, o gosto pelo novo, pela sedução efêmera e pelo individualismo.

A moda situa-se no cruzamento entre roupa e vestuário, entre aquilo que o indivíduo pode introduzir no sistema até torná-lo patrimônio comum, e aquilo que é introduzido e reproduzido em escala coletiva, por exemplo, a haute couture. Nessa relação está talvez escrita a lei das transformações que atuam no setor: 0 significado daquilo que se veste cresce à medida que se passa do ato pessoal ao gesto comum. [...] Estudar a moda equivale, nessa perspectiva, a estudar as relações sociais e as características da sua evolução. (CALANCA, 2008, p. 27)

Compreender a realidade do passado por meio de representações, reconstruir o não vivido e o não visto a partir de registros, imagens, traços, vestígios e fragmentos de outro tempo, portanto, é uma das propostas das representações também pertinentes ao cinema e à moda. As duas grifes dialogaram com o imaginário de suas respectivas épocas, fazendo uma releitura do figurino, capturando o novo em suas coleções, apresentando uma gama de diversidade, liberdade, fantasia e sedução. Assim, torna-se claro que, a partir dos mundos ficcionais criados pelas artes visuais, é possivel apreender a diversidade das representações culturais e sociais, tornando possivel a compreensão do processo de transformação pelo qual a moda se recria, modificando-se e adaptando-se ao novo contexto sociopolítico.

[Recebido em: 15/04/2016]

[Aprovado em: 27/07/2016]

\section{NOTAS}

[1] Disponivel em: <http://www.contracampo.com.br/68/visconticitacoes.html>. Acesso em: 13 abr. 2016.

${ }^{[2]}$ Cf. MERTEN, Luiz Carlos. Os deuses malditos, 0 Estado de São Paulo, 13 de maio de 2012. Disponível em: <http://cultura.estadao.com.br/blogs/luiz-carlos-merten/os-deuses-malditos/>. Acesso em: 13 abr. 2016.

${ }^{[3]}$ Disponivel em: <http://www.revistas.usp.br/discurso/article/viewFile/37723/40450>. Acesso em: 13 abr. 2016. 


\section{REFERÊNCIAS}

AGAMBEN, Giorgio. 0 que é o contemporâneo? Chapecó: Argos, 2009.

ANDRADE, Rita. 0 caso do vestido e a biografia cultural das roupas. Anais do XXVI Simpósio Nacional de História. ANPUH. São Paulo, jul. 2011.

BARTHES, Roland. 0 sistema da moda. São Paulo: Martins Fontes, 2009.

BARNARD, Malcolm. Moda e comunicação. Rio de Janeiro: Rocco, 2003.

BENJAMIN, Walter. Obras Escolhidas III. Charles Baudelaire: um lírico no auge do capitalismo. São Paulo: Brasiliense, 1989.

BONADIO, Maria Claudia \&t MATTOS, Maria de Fátima S. Costa G. História e cultura de moda. São Paulo: Estação das Letras e Cores, 2011.

CALANCA, Daniela. História social da moda. São Paulo: Ed. Senac São Paulo, 2008.

CASTILHO, Kathia. Moda e linguagem. São Paulo: Anhembi Morumbi, 2009

DIEGO, Marcelo da Rocha Lima. Em busca do filme perdido: presença proustiana na Morte em Veneza de Luchino Visconti. Revista Garrafa, ed. 22, set.-dez. 2010.

FOGG, Marnie. Tudo sobre moda. Rio de Janeiro: Sextante, 2013.

LAGNY, Michele. Visconti ou como inventar uma crítica da História graças ao cinema. Revista Esboços, Florianópolis, v. 19, n. 27, pp. 140-149, ago. 2012

LIPOVESTKY, Gilles. 0 império do efêmero: a moda nas sociedades modernas. São Paulo: Companhia das Letras, 1989.

Os tempos hipermodernos. São Paulo: Barcarolla, 2004.

LOPES, Denilson. Aquém e além do cinema moderno: Visconti, melancolia e neobarroco. Revista Novos Estudos CEBRAP, n. 53„pp. 205-211, mar. 1999.

MANN, Thomas. Morte em Veneza. Tradução de Eloisa Ferreira Araújo Silva. Rio de Janeiro: 0 Globo; São Paulo: Folha de S. Paulo, 2003.

MARQUES, Adair \& PEREIRA, Flávio. Arte, moda, literatura e cinema: saberes compartilhados. In: CHAUD, E.; SANT'ANNA, T.F. (Org.). Anais do VII Seminário Nacional de Pesquisa em Arte e Cultura Visual. Goiânia-GO: UFG, FAV, 2014. ISSN 2316-6479.

MEIMES, Leonardo Telles. Literatura e cinema: o entremeio na adaptação de 0 Gattopardo por Luchino Visconti.Let, São Paulo, v. 52, n. 1, pp. 177-197, jan./jun. 2012.

MESOUITA, Cristiane; PRECIOSA, Rosane (Orgs.). Moda em ziguezague: interações e expansão. São Paulo: Estação das Letras e Cores, 2011.

OLIVEIRA, Sandra Ramalho e. Moda também é texto. São Paulo: Editora Rosari, 2008.

PAULINI, Marcelo. A constelação Proust-Visconti/Marcelo MotitPeccioliPaulini. Campinas, SP (S.N), 2010. Tese (Doutorado em Letras) - Instituto de Estudos da Linguagem, Universidade Estadual de Campinas.

SOARES, Kárita Garcia. Acervos de figurino teatral: considerações gerais.CONGRESSO INTERNACIONAL DE MEMÓRIA, DESIGN E MODA. São Paulo, 2014. pp. 134-144.

STALLYBRASS, Peter. 0 casaco de Marx: roupas, memória, dor. Belo Horizonte: Autentica Editora, 2008.

SOUZA, Gilda de Mello e. Os deuses malditos (escrito em colaboração com Antônio Cândido). In: Exercícios de Leitura. 2. ed. São Paulo: Livraria Duas Cidades/Editora:34, 2009.

STAM, Robert. A literatura através do cinema: realismo, magia e arte da adaptação. Belo Horizonte: UFMG, 2008.

SVENDSEN, Lars. Moda, uma filosofia. Rio de Janeiro: Zahar, 2010. 


\section{IMAGENS}

$<$ <ttp://www.blogsoestado.com/emcartaz/files/2013/05/Leopardo-1>.

<https://s-media-cache-ak0.pinimg.com/564x/88/4f/84/884f846e1e09690554cb90152663a396. jpg>.

$<$ <ttps://fashionview.files.wordpress.com/2009/05/210520091651071910227008. jpg?w=304Cth=448>.

<https://armonte.files.wordpress.com/2011/02/morte_em_veneza1.jpg>.

<https://s-media-cache-ak0.pinimg.com/564x/88/4f/84/884f846e1e09690554cb90152663a396. jpg>.

<http://2.bp.blogspot.com/ xFZOBO7050/Sg3MmM4SkHI/AAAAAAAABjk/qg9NelxQfrc/s400/ CHANEL.jpg>.

$<$ <ttp://www.abril.com.br/imagem/chanel-cruise-collection-2010-05g.jpg>.

$<$ <ttp://www.estilovanguarda.com.br/wp-content/uploads/2009/05/c5.jpg>.

<http://api.ning.com/files/OHO*5vFbdAxlAnlyBNphbPpFd6AvnpLioYzjPdEdiOsOpdlixOn9doom7BLq I5KVjYB5oomMzsBgB8Vo5kxSGhSi-vf8ZoOd/bjornandresen1>. <http://2001video.empresarial.ws/ blog/wp-content/uploads/2012/05/203.jpg>.

$<h t t p: / / m e m o r i a l d a f a m a . c o m / a r t i s t a s / H e l m u t B e r g e r 3 . j p g>$.

<http://ffw.com.br/app/uploads/desfiles/2015/03/miumiu-rtw-paris-inverno2016-3.jpg>.

$<h t t p: / / w w w . l i l i a n p a c c e . c o m . b r / d e s f i l e / m i u-m i u-p r e-o u t o n o-i n v e r n o-201617>$. 